\title{
MODERN EUROPEAN REQUIREMENTS \\ FOR EDUCATIONAL PROGRAMS \\ IN HIGHER EDUCATIONAL INSTITUTIONS OF UKRAINE
}

\section{Pochuieva Olha ${ }^{1}$}

DOI: dx.doi.org/10.30525/978-9934-571-30-5_30

\begin{abstract}
The article analyzes the requirements, mechanisms of development and implementation of educational programs determined by the current legislation. Stages of education are considered in Ukraine as well as requirements for educational programs. European and National qualifications frameworks were characterized on the assumption of the distinguished degrees of education and the comparison of its descriptors was conducted. A generalization of each stage was made on the grounds of algorithm of higher education standards. European Standards (ESG) and recommendations for the educational programs development were analyzed. Key profile positions of degree programs of instructional guidelines for TUNING project were reviewed. The obtained results of the European projects analysis on account of the improvement of the higher educational system (ESG), the development and update of educational programs (TUNING), the harmonization of educational programs and qualifications frameworks (ALIGN) facilitate the integration of Ukraine higher education into the European space through the implementation the conditions and policies of the Bologna process. The results of generalizations and developments may be aimed at developing and improving indicators of domestic quality assurance of higher education.
\end{abstract}

\section{Introduction}

Integration of Ukraine higher education into the European space through the implementation the conditions and policies of the Bologna process; quality assurance of higher education and science by virtue of the

\footnotetext{
${ }^{1}$ Candidate of Pedagogical Sciences,

Chief specialist of the Department of Education Quality Assurance and Innovation Development, Lecturer of the Department of Foreign Languages,

Simon Kuznets Kharkiv National University of Economics, Ukraine

ORCID: http://orcid.org/0000-0001-6954-5197
}

(C) Pochuieva Olha 


\section{Pochuieva Olha}

independent system development of higher education quality assurance; integration of education, science and innovation; autonomy of higher educational institutions; cooperation of higher educational institutions and business in the field of higher education and science through the introduction of mechanisms for innovation development of the country by means of the interaction of education, science, business and the state - all of it determines the conceptual framework for the modernization of higher education. The Law of Ukraine "On Higher Education" (2014) grants the autonomy for higher educational institutions and promotes the development of the education content; provision of educational services quality; the competitiveness of graduates in the labor market. The autonomy of the higher educational institution is defined in the mentioned Law as the independence, self-sufficiency and responsibility of the higher educational institution in making decisions on the academic freedoms development, the organization of educational process, scientific research, internal management, economic and other activities, recruitment and deployment of personnel [4]. In this context, higher educational institutions should be able to develop educational programs for the training of specialists.

The educational program is defined as an concerted body of educational activities, whose development and implementation should be based on a competency building approach taking into account the current regulatory framework, namely the Laws of Ukraine "On Education" (2017), "On Higher Education" (2014), the Resolutions of the Cabinet of Ministers of Ukraine "On Approval of Licensing Conditions for Educational Activities of Educational Institutions" (2015), "On Approval of the National Qualifications Framework" (2011), "Methodological Recommendations of the MESU on the Development of Higher Education Standards" (2016). It should meet the standards and recommendations adopted by the Ministerial Conference in Yerevan "Standards and Guidelines for Quality Assurance in the European Higher Education Area (ESG)" (2015), the results of the European Commission's Project "Tuning Educational Structures in Europe" reflected in "Guidelines and Reference Points for the Design and Delivery of Degree Programmes" including programs of competencies and training outcome (Tuning Educational Structures in Europe, TUNING, 2016), the TEMPUS international project of the European Union "ALIGN: Achieving and Checking the Alignment between Academic Programmes and Qualification Frameworks" (2017), the results of which are represented in 
the "National Guidelines for the Harmonization of Academic Programmes and Qualifications Frameworks".

S. Kalashnikova, T. Lukina, Y. Rashkevych considered the question of the quality assurance problem in the works of; I. Zolotorova, V. Kovtunets, S. Kalashnikov, S. Kurbatov, I. Lynova, I. Prokhor examined evaluation of the quality of educational programs and foreign experience in the works; S. Kalashnikova, S. Kurbatova, I. Prokhor, I. Sikorska dedicated their works to the mechanisms providing and improving the quality of higher education; Y. Rashkevych, O. Sharov presented the system of external evaluation of higher education quality; V. Zakharchenko, V. Lugovyi, Y. Rashkevych, and J. Talanova evaluated the issues of monitoring and improving the educational program in their works.

\section{Research methodology}

We used the following research methods in order to study the normative legal framework of Ukraine and generalize the main European requirements regarding the content of educational programs: analysis, synthesis, generalizing.

\section{Discussion}

Accession of Ukraine to the Bologna process, integration into the European higher education area and adoption of the new Laws of Ukraine "On Education" and "On Higher Education" allot topical tasks on higher educational institutions above all to build up and implement educational programs on grounds of the competence approach.

According to the Law of Ukraine "On Higher Education" (Article 5), the training of specialists with higher education is carried out in conformance with the relevant educational and professional, educational and scientific and scientific programs at the following levels of higher education: the initial level (short cycle) of higher education; the first (bachelor's) level; the second (master's) level; the third (educational and scientific) level; scientific level.

Acquaintance of higher education at each level of higher education involves the successful completion of a relevant educational (educational and professional or educational and scientific) or scientific program by an individual, which is the basis for awarding the corresponding degree of higher education: Junior Bachelor; Bachelor; Master; Doctor of Philosophy/ Doctor of Arts; Doctor habil. [4]. 
Table 1 vividly represents a comparison of levels, degrees and educational programs of the higher education system.

Table 1

\section{Levels, Education Degrees and Education Programs of the Higher Education System of Ukraine}

\begin{tabular}{|l|c|c|}
\hline $\begin{array}{c}\text { Level of } \\
\text { education }\end{array}$ & Degree of education & Educational program \\
\hline Initial & Junior Bachelor & educational and professional \\
\hline First & Bachelor & educational and professional \\
\hline Second & Master & educational and professional \\
\cline { 3 - 3 } & educational and scientific \\
\hline Third & $\begin{array}{c}\text { Doctor of Philosophy (PhD) } \\
\text { (first academic degree) }\end{array}$ & educational and scientific \\
\hline Scientific & Doctor habil. (second academic degree) & \\
\hline
\end{tabular}

Analyzing the data of Table 1 it can be stated that appropriate educational and professional or educational and scientific programs should be developed for each degree at all levels of higher education.

Let's take a closer look at the degree of education and the requirements for educational programs defined in Article 7 of the Law of Ukraine "On Higher Education" [4].

Junior Bachelor is educational and professional degree acquired at the initial level (short cycle) of higher education and awarded by the higher educational institution as a result of the successful fulfilment of an educational and professional program by the applicant for higher education, which volume is 120-150 ECTS credits. The volume of the educational and professional program is determined for obtaining the degree of a junior bachelor on the basis of a Junior Specialist degree by the institution of education.

Bachelor is an educational degree obtained at the first level of higher education and awarded by a higher educational institution as a result of the successful fulfilment of fulfilment of an educational and professional program by the applicant for higher education, which volume is 180-240 ECTS credits. The volume of the educational and professional program is determined for obtaining the degree of a Bachelor on the basis of a Junior Bachelor or Junior Specialist degree by the institution of higher education. 
Master is an educational degree acquired at the second level of higher education and awarded by a higher educational institution (scientific establishment) as a result of successful fulfilment of a relevant program by the applicant for higher education. A master's degree is obtained through an educational and professional or an educational and scientific program. The volume of the educational and professional program of the master's degree training includes 90-120 ECTS credits, the volume of educational and scientific program is 120 ECTS credits. The master's educational and scientific program indispensably includes a research (scientific) component of at least 30 percent.

Doctor of Philosophy is an educational and, at the same time, the first scientific degree and a degree obtained at the third level of higher education on the basis of a master's degree. Specialized academic council awards the degree of Doctor of Philosophy at a higher educational institution or a research institution as a result of successful fulfilment of relevant educational and scientific program and public defense of a thesis in a specialized academic council by an applicant for higher education. The normative training period is four years for the Doctor of Philosophy at the postgraduate study (adjuncture). The volume of the educational component of the educational and scientific program includes 30-60 ECTS credits for the training of the Doctor of Philosophy.

Doctor habil. is the second scientific degree obtained by an individual at the scientific level of higher education on the basis of the degree of the Doctor of Philosophy and involves the acquisition of the highest competencies in the field. Educational component is not required for this degree of education in accordance with the current legislation.

Proceeding from given the degrees of education, the mechanisms harmonizing educational programs with the European and National Qualifications Frameworks are urgent. The outlined issue is relevant, since the level of qualification to be awarded should be determined during the development of an educational program of the HEI, which grounds on the basis of the current legislation and the existing European Qualifications Frameworks. Let's analyze in more detail this issue relying on the researches by V. Zakharchenko, Y. Rashkevych, J. Talanova [3].

Today two basic qualifications frameworks are developed and used in Europe. The Framework of Qualifications for the European Higher Education Area (QF EHEA) and The European Qualifications Framework for lifelong learning (EQF LLL). 


\section{Pochuieva Olha}

The given qualification frameworks are compatible, since levels 6, 7 and 8 of the EQF LLL correspond to the three cycles of the QF EHEA, which provides the possibility of developing short-cycle educational programs (corresponding to the level 5 of the EQF LLL) in the national qualifications frameworks within the first cycle (bachelor's studies).

The Framework of Qualifications for the European Higher Education Area (QF for the EHEA) was adopted at the European Ministerial Conference on education in $2005[6 ; 7 ; 12]$.

QF for the EHEA are the structures that describe the qualifications of higher education of countries participating in the Bologna Process. This qualification framework is designed for higher educational institutions/ institutions of higher education in Europe. It characterizes three consecutive higher education cycles, as well as a short cycle [3]:

- the short - 90-120 credits;

- the first (Bachelor's) - 180-240 credits;

- the second (Master's) - 90-120 credits;

- third (Doctoral) - 30-60 credits.

The QF for the EHEA is based on Dublin descriptors.

The Dublin descriptors describe in short form the typical expected accomplishments and abilities associated with the qualifications relating to the termination of each higher education Bologna cycles. It does not partake a regulatory nature, does not represent a threshold or minimum requirements, it is not exhaustive; it can be replaced and analogous or equivalent characteristics can be added. The descriptors are aimed at determination the character of the integral qualification [1]:

Dublin descriptors of fundamental general competencies:

1. Knowledge and understanding.

2. Applying knowledge and understanding.

3. Making judgements.

4. Communication.

5. Learning skills.

On the basis of these descriptors, it is possible to classify educational programs according to the levels of qualification, compare it against each other and acknowledge documents on higher education.

The European Qualifications Framework for lifelong learning (EQF for LLL) was adopted by the European Parliament and the Council of the European Union in 2008 [3; 6; 7; 13]. 
EQF for LLL is a general system description of eight (1-8) qualification levels covering the full range of qualifications obtained through formal, non-formal, informal learning, in particular general secondary, vocational and higher education. The descriptors of the qualification levels of the EQF LLL are following:

- knowledge (theoretical and/or factual);

- skills (cognitive and practical);

- competences (autonomy and responsibility).

The National Framework of Qualifications (NFQ) was approved in Ukraine by the Resolution of the Cabinet of Ministers of Ukraine dated November 23, 2011 No. 1341 "On Approval of the National Qualifications Framework" [10]. The structure contains a description of ten qualification levels (from 0 to 9) covering all levels of the national education system.

However, it should be noted in this aspect that Article 35 of the Law of Ukraine "On Education" (2017) stipulates that a national and sectoral qualifications framework operate in Ukraine. Article 36 of the same Law stipulates that the National Qualifications Framework determines eleven levels (from 0 to 10). Each level of the NQF is determined by the aggregate of the competencies of the individual, typical for the qualifications of the relevant level, which also includes the readiness of the individual for lifelong learning.

The main descriptors of the NQF are:

- knowledge;

- skills (cognitive and practical);

- communication;

- autonomy and responsibility [10].

Table 2 represents the comparison of the descriptors of the European and National qualifications frameworks.

In general, the system of descriptors of the national NQF is consistent with both the European Qualifications Framework for lifelong learning and the Framework of Qualifications for the European Higher Education Area. The key descriptors having been accounted by the NQF from the European Qualifications Frameworks are knowledge, skills, communication, autonomy and responsibility.

The NQF is approved as a generalized structure in Ukraine, by which the qualifications (educational and professional) should be described and compared, it does not include the titles and description of specific 


\section{Comparison of the European and national qualifications frameworks descriptors}

\begin{tabular}{|l|l|l|}
\hline \multicolumn{1}{|c|}{ EQF for LLL } & \multicolumn{1}{c|}{ QF for the EHEA } & \multicolumn{1}{c|}{ NQF } \\
\hline - knowledge and & - knowledge (theoretical & - knowledge; \\
understanding; & and/or factual); & - skills (cognitive and \\
- applying knowledge and & - skills (cognitive and & practical); \\
understanding; & practical); & - communication; \\
- making judgements; & - competences (autonomy & - autonomy and \\
- communication; & and responsibility). & responsibility. \\
- learning skills; & & \\
\hline
\end{tabular}

qualifications, types of qualifications, in particular qualifications of higher education. So far, NQF certification was not carried out in Ukraine, and therefore the NQF is not formally associated with the European Qualifications Frameworks. The projected comparison is given below for qualification levels of NQF related to higher education with qualification levels of the European Qualifications Framework for lifelong learning and cycles of the Framework of Qualifications for the European Higher Education Area in Table $3[1 ; 10]$.

Having examined the main aspects of the European and the features of the National Qualifications Frameworks regarding the levels and qualifications of higher education, the requirements and mechanisms should be considered for the development and implementation of educational programs as defined by the current legislation.

The Law of Ukraine "On Education", the section IV "Standards of Education, Educational Programs, Qualifications and Education Documents", in particular Article 33, reveals the main requirements for educational programs [5].

The educational program should include:

- requirements for persons who can start the program;

- a list of educational components and its logical consistency;

- the total amount of study load and the expected results of training for education applicants.

Institutions of education, scientific establishments and other subjects of educational activity develop educational programs and it is approved in accordance with this Law and special laws. Educational programs should include educational components for the free choice of education applicants. 


\section{Comparison of the qualification levels of the NQF} and the innovations of the Law of Ukraine "On Education" with the European Qualifications Frameworks

\begin{tabular}{|c|c|c|c|c|c|}
\hline $\begin{array}{l}\text { EQF } \\
\text { for } \\
\text { LLL }\end{array}$ & $\begin{array}{c}\text { QF } \\
\text { for the } \\
\text { EHEA }\end{array}$ & $\begin{array}{c}\text { NQF } \\
\text { dated } \\
\text { 23.11.2011 } \\
\text { No. } 1341\end{array}$ & $\begin{array}{c}\text { Qualifications } \\
\text { of Higher } \\
\text { Education in } \\
\text { accordance } \\
\text { with the NQF } \\
\text { dated } \\
23.11 .2011 \\
\text { No. } 1341 \\
\end{array}$ & $\begin{array}{c}\text { Law of Ukraine } \\
\text { "On Education" } \\
\text { dated 05.09.2017 } \\
\text { No. 2145-VIII }\end{array}$ & $\begin{array}{c}\text { Levels of education } \\
\text { in accordance with the } \\
\text { Law "On Education" } \\
\text { Dated 05.09.2017 } \\
\text { No. 2145-VIII }\end{array}$ \\
\hline & & Level 0 & & Level 0 & preschool education \\
\hline Level 1 & & Level 1 & & Level 1 & primary education \\
\hline \multirow[t]{2}{*}{ Level 2} & & \multirow[t]{2}{*}{ Level 2} & & \multirow[t]{2}{*}{ Level 2} & basic secondary education \\
\hline & & & & & $\begin{array}{l}\text { the first (initial) level of } \\
\text { vocational education }\end{array}$ \\
\hline \multirow[t]{2}{*}{ Level 3} & & \multirow[t]{2}{*}{ Level 3} & & \multirow[t]{2}{*}{ Level 3} & industry-specific education \\
\hline & & & & & $\begin{array}{l}\text { the second (basic) level of } \\
\text { vocational education }\end{array}$ \\
\hline Level 4 & & Level 4 & & Level 4 & $\begin{array}{l}\text { the third (higher) level of } \\
\text { vocational education }\end{array}$ \\
\hline Level 5 & $\begin{array}{l}\text { short } \\
\text { cycle }\end{array}$ & Level 5 & & Level 5 & pre-tertiary education \\
\hline Level 6 & $\begin{array}{l}\text { the first } \\
\text { cycle }\end{array}$ & Level 6 & $\begin{array}{l}\text { Junior } \\
\text { Bachelor }\end{array}$ & Level 6 & $\begin{array}{c}\text { initial level (short) cycle } \\
\text { level of HE }\end{array}$ \\
\hline Level 7 & $\begin{array}{l}\text { the } \\
\text { second } \\
\text { cycle }\end{array}$ & Level 7 & Bachelor & Level 7 & $\begin{array}{l}\text { the first (Bachelor's) level } \\
\text { of HE }\end{array}$ \\
\hline \multirow[t]{3}{*}{ Level 8} & $\begin{array}{c}\text { the third } \\
\text { cycle }\end{array}$ & Level 8 & Master & Level 8 & $\begin{array}{c}\text { the second (Master's) level } \\
\text { of HE }\end{array}$ \\
\hline & & Level 9 & $\begin{array}{l}\text { Doctor of } \\
\text { Philosophy }\end{array}$ & Level 9 & $\begin{array}{c}\text { educational and scientific/ } \\
\text { educational and creative } \\
\text { level of HE }\end{array}$ \\
\hline & & & Doctor habil. & Level 10 & scientific level of HE \\
\hline
\end{tabular}

Educational establishments may use standard or other educational programs developed and approved in accordance with this Law and special laws.

The system of external quality assurance of education includes the accreditation of educational programs. Article 44 of the Law of Ukraine "On Education" stipulates that the accreditation of the educational program is the assessment of the educational program against the standard 


\section{Pochuieva Olha}

of education, as well as the capacity of the educational institution to ensure the achievement of the results of education provided by the educational program. Accreditation of the educational program is voluntary and conducted due to the initiative of the educational institution. The educational program is accredited if it is provided for by a special law. Special laws determine principles of accreditation of educational programs. Quality assurance authority accredits the educational program of the relevant level of education according to the special law as well as accredited public professional associations or other accredited legal entities conducting an independent assessment of the quality of education and educational activities in educational institutions [5].

The standard of higher education (Article 10, item 3) defines the following requirements for an educational program in the Law of Ukraine "On Higher Education", in Section III "Standards of Educational Activities and Higher Education":

1) the amount of ECTS credits necessary for obtaining a corresponding degree of higher education;

2) the list of competences of the graduate;

3) the normative content of the training of higher education applicants formulated in terms of learning outcomes;

4) forms of examination for higher education applicants;

5) requirements for the existence of an internal quality assurance system for higher education;

6) requirements of professional standards (if any) [4].

The institution of higher education develops a curriculum for each specialty on the basis of the relevant educational program, which defines the list and volume of academic disciplines in ECTS credits, the sequence of studying disciplines, the forms of training sessions and its amount, the schedule of the educational process, the forms of current and final control.

Individual curricula for students are to be developed and approved on the grounds of the curriculum in accordance with the prescribed procedure by HEI, and it must include among others selected academic disciplines by higher education applicants.

The institution of higher education may introduce specialties, the list of which is determined by the higher educational institution within the limits of its licensed specialty. 
In addition to the requirements specified in Article 16, item 2, the necessity is specified of monitoring and periodicity of the educational programs revision and item 7 provides for publicity of information on educational programs, degrees of higher education and qualifications [4].

Methodological Recommendations on the Development of Higher Education Standards approved by the order of the Ministry of Education and Science of Ukraine dated 01.07.2016 No. 600 disclose in more detail mechanism of standards developing for higher education upon which educational programs are being developed [9].

In methodological recommendations defines the "Standard of Higher Education" as a set of requirements for the content and results of educational activities of higher educational institutions and scientific institutions at each level of higher education within each specialty.

Higher education standards are developed for each level of higher education within each specialty in accordance with the National Qualifications Framework (NQF).

Higher education standards are used to determine and assess the quality of the content and results of educational activities of higher educational institutions (scientific establishments).

The higher education standard distinguishes the following requirements for an educational program:

1) the amount of ECTS credits necessary for obtaining a corresponding degree of higher education;

2) the list of competences of the graduate;

3 ) the normative content of the training of higher education applicants formulated in terms of learning outcomes;

4) forms of examination for higher education applicants;

5) requirements for the existence of an internal quality assurance system for higher education;

6) requirements of professional standards (if any).

A higher educational institution or a scientific establishment relying on an educational program (EP) develops a curriculum for each specialty defining:

- list and volume of academic disciplines in ECTS credits;

- sequence of studying disciplines;

- forms of holding training sessions and its volume;

- schedule of the educational process;

- forms of current and final control. 


\section{Pochuieva Olha}

The head of the higher educational institution or a scientific institution approves working curriculum schemed to specify the planning of the educational process for each academic year.

New standards for higher education are the next generation of standards and supersede the Sectoral Standards for Higher Education (SSHE) developed in 2002-2014 in accordance with the law. Standards rest upon a competence approach and share the philosophy of defining the requirements for a specialist adopted from the Bologna Process and the international Project of European Commission "Tuning Educational Structures in Europe" (TUNING).

Fig. 1 vividly illustrates consecutive sections of the development structure algorithm of the Standard for Higher Education.

Let's characterize nine sections of the structure of the Standard for Higher Education.

Section I "Preface". The section specifies the initial data of the Standard (title, date, order number); the extended information is indicated of the Standard developers (name, patronymic, scientific degree, academic rank, position and title of the organization they work); data is provided on the review and approval of the Standard, information is reported on the proposals by the sectoral government bodies, to which the higher education institutions belong, and sectoral associations of employer organizations; the date and order number of the National Agency for Quality Assurance in Higher Education having agreed upon the Standard for Higher Education.

Section II "General characteristics" consists of such parameters as the level of higher education determined by Art. 5 of the Law of Ukraine "On Higher Education" (initial level (short cycle) of higher education, the first (bachelor) level, the second (master) level, the third (educational and scientific) level; the degree of higher education determined by Art. 5 of the Law of Ukraine "On Higher Education" (Junior Bachelor, Bachelor, Master, Doctor of Philosophy); the branch of knowledge and specialty determined by the Resolution of the Cabinet of Ministers of Ukraine dated 29.04.2015 No. 266; educational qualification defined in Article 7 of the Law of Ukraine "On Higher Education" consisting of information on the degree of higher education gained by an individual, specialty and specialization (if any); qualification in the diploma consists of an educational qualification (specialty is indicated if available) and professional qualification; the description of the subject area determined in accordance 


\section{Chapter 13. Pedagogical sciences}

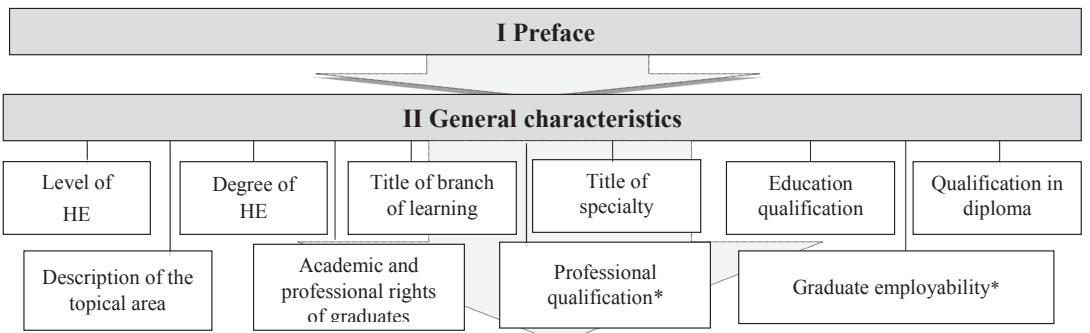

III Volume of ECTS credits required to gain a relevant degree of higher education

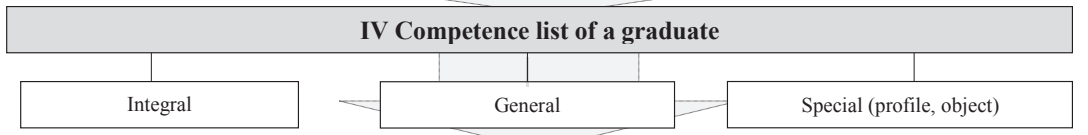

V Normative content of the training formulated in terms of learning outcomes

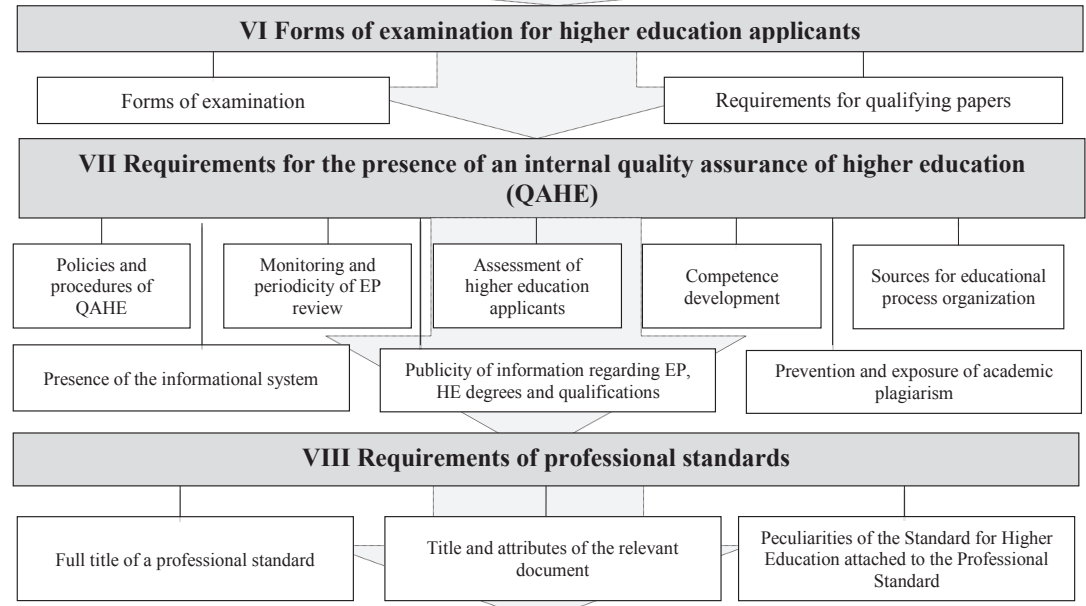

IX List of regulations, upon which the Standard for Higher Education grounds

Fig. 1. Development structure algorithm of the standard for higher education

with item 15 of the ISCED-F 2013 (subject(s) of study and/or activity, objectives of training, theoretical content of the subject area, methods, techniques and technologies, tools and equipment); academic graduate 


\section{Pochuieva Olha}

rights, described opportunities, requirements and/or recommendations for continuing education; employment of graduates; indicated professions, professional titles of works (according to the current edition of the National Classification of Ukraine: Classification of Occupations (DK 003:2010) and International Standard Classification of Occupations 2008 (ISCO-08)).

Section III "Volume of ECTS credits required to gain a relevant degree of higher education". The volume of educational programs is determined in ECTS credits, the quantitative indicators of which is defined by the Law of Ukraine "On Higher Education".

Section IV "Competencies list of a graduate" consists of three blocks of competences: integral (using the description of the higher education level, corresponding qualification level of the National Qualifications Framework (NQF)); general (the list of general competences is correlated with the description of the corresponding qualification level of the NQF. It is recommended to select the general competencies from the list of the TUNING project (5-15 competencies taking into account the level of education)); special (profile, object) (the list of competences also correlates with the description of the qualification level of the NQF. It is recommended to select special (profile, object) competences from the TUNING project list (10-20 competences taking into account the level of education)).

Particular attention should be paid to the fact that the competences of the graduate reflect the views of external customers: employers, professional associations, graduates, etc. on education and/or vocational training and it should maximize employability.

Section V "Normative content of the training formulated in terms of learning outcomes". The results, outcomes and integrative learning effects are defined by the Standard to determine the normative content of the training. The total number is $15-25$ learning outcomes correlating with the above list of general and special (profile, object) competences. The usage of one among the recognized classifications, in particular, by the authorship of B. Bloom is recommended to ensure consistency and identity in the description of the learning outcomes.

Section VI "Forms of examination for higher education applicants". The section defines the forms of examination for higher education applicants, requirements for qualifying work, requirements for the attestation/unified state qualification exam (exams) and requirements for public defense (demonstration). 
Section VII "Requirements for the presence of an internal quality assurance of higher education". The quality management system should be implemented for education activity and higher education in the HEI (system of internal quality assurance), which ensure the applying of the procedures and measures presented in Figure 1.

Section VIII "Requirements of professional standards (if any)". Information is noticed on available professional standards (of national and international organizations) (document title, attributes and/or references) introduced in the Standard for Higher Education and (or) which are important for taking into account while constructing and implementing the educational (educational and professional) programs. Provision of this information is obligatory in case of reference of professional qualification awarded to graduates in the standard.

The educational program is being developed by the graduate project team of the department (inter-departmental group), approved by the academic council of the University and put into operation by the order of the rector.

According to Article 30 of the Law of Ukraine "On Education" [5] and Article 16 of the Law of Ukraine "On Higher Education" [4], higher educational institutions should provide publicity information on educational programs, degrees and qualifications on their websites. Educational programs developed at the Kharkov National Economic University named after Semen Kuznets and placed in the free access on the university's website http://www.hneu.edu.ua/Educational_programs_KhNUE are considered as an example of the requirements accounting of the Laws of Ukraine "On education", "On higher education" and the methodological recommendations of the MESU.

Let's analyze European standards and guidelines on the development of educational programs.

Standards and Guidelines for Quality Assurance in the European Higher Education Area (ESG) [2].

ESG is a set of standards and recommendations for both internal and external assurance of quality and learning environments in higher education.

The key objective of the "Standards and Guidelines for Quality Assurance in the European Higher Education Area (ESG)" is to promote a common understanding of the quality of teaching and learning, regardless of the frontier between all stakeholders.

The ESG has the following objectives: 


\section{Pochuieva Olha}

- establishment of a common framework for quality assurance in teaching and learning at European, national and institutional levels;

- promotion the provision and improvement of the quality of higher education in the European Higher Education Area;

- support of mutual trust. Facilitating recognition and mobility within and beyond national boundaries;

- providing information on quality assurance in the EHEA [2].

ESG grounds on the four principles of quality assurance in the European Higher Education Area, namely:

- higher educational institutions have a certain responsibility for the quality of the provided higher education;

- quality assurance corresponds to the diversity of the system of higher education, higher educational institutions, programs and students;

- quality assurance contributes to the development of a quality culture;

- quality assurance caters to the needs and expectations of students, all other stakeholders and society.

Components of policies and procedures managing the quality of a HEI (ESG):

1. Quality assurance policy.

2. Development and approval of educational programs.

3. Student-centered training, teaching and assessment.

4. Matriculation, achievement, recognition and attestation of students.

5. Teaching staff.

6. Educational resources and student support.

7. Information management.

8. Public information.

9. Current monitoring and periodic review of programs.

10. Cyclic external quality assurance [2].

The quality assurance standards are divided into three parts: internal, external and quality assurance agencies. The identified parts are interconnected and form together the basis of the European Quality Assurance Framework. Standards and guidelines for the development of educational programs are considered as part of the internal quality assurance.

The part of development and approval of educational programs stipulates in the standard of this direction that institutions should implement the process of developing and approving its programs. 
The following requirements are put forward in accordance with the recommendations to the educational programs:

- educational programs should be located at the center of the institution mission related to teaching; meet the institutional strategy and take determined and expected effect;

- the development of an educational program takes place with the active involvement of students and stakeholders;

- the four objectives of the Council of Europe are desirable to be reflected for higher education in the structure of the educational program;

- educational programs should be designed in such a way the student to have the opportunity to obtain academic knowledge and skills in the learning process that can affect professional development and personal growth.

According to the ESG guidelines, one of the key requirements for developing an educational program is student-centered learning and teaching. Higher educational institutions should ensure the programs implementation in such a way to encourage students to take an active part in the development of the educational process, and student assessment should reflect this approach. Therefore, this aspect plays an important role in stimulating student motivation, introspection and involvement to the educational process and facilitates the inclusion of students in the process of developing, implementing educational programs in general and evaluating learning outcomes in particular.

The introduction of student-centered learning and teaching is such that it:

- respects and takes into account the diversity of students and their needs, enabling flexible learning trajectories;

- considers and uses different ways of providing educational services;

- flexibly uses various pedagogical methods;

- regularly evaluates and adjusts the methods providing educational services and pedagogical methods;

- promotes mutual respect in the relations of "student-teacher";

- includes proper procedures for examining student complaints.

Quality assurance procedures for evaluation envisage:

- students are familiar with the existing methods of testing and examinations and receive support for developing their own skills in this area;

- criteria and methods of evaluation are made public in advance;

- the assessment allows students to demonstrate the extent to which the planned results have been achieved. 


\section{Pochuieva Olha}

The ESG guidelines focus on information management, public information, current monitoring and periodicity of viewing educational programs. Let's examine each of these directions in more detail and determine the key issues.

Information management. The standard states in this area that institutions should ensure the collection, analysis and use of relevant information for the effective management of its educational programs. Effective processes collecting and analyzing information about educational programs and other activities support the system of internal quality assurance. The satisfaction of students with educational programs is the key argument for the development and update of educational programs.

Public information. The standard states in this area that institutions should publish clear, accurate, objective, timely and easily accessible information on its activities, in particular on educational programs. Presented public information on the higher institution and educational programs particularly should be directed and useful for entrants, students, graduates and employers. Public information should include in its structure: a list of educational programs and requirements for entrants, cut-off score; planned learning outcomes for these educational programs; training, teaching and assessment procedures; additional opportunities available to the student; as well as information on the employment of graduates.

Current monitoring and periodicity of program review. The standard of this direction specifies that institutions should monitor and periodically review educational programs. The guidelines of this standard are to conduct regular monitoring, as well as to create a supportive and effective learning environment. Content of the program, the needs of society, student workload, the effectiveness of student assessment procedures are subject to monitoring. Students and stakeholders should be involved in the process of reviewing and updating programs [2].

Summarizing the ESG standards and guidelines for the development and approval of educational programs the following conclusions may be drawn. Establishments should implement the processes of developing and approving their educational programs. Programs should be designed in such a way to meet their intended goals including the planned learning outcomes. The qualifications should be clearly identified in order to obtain it as a result of studying the program. The educational program should correspond to a certain level of the NQF, as well as the Framework for the European Higher Education Area. 


\section{Chapter 13. Pedagogical sciences}

European Commission project "Tuning Educational Structures in Europe", TUNING.

In the conditions of internationalization and the creation of a single European higher education area designed to increase the competitiveness of European universities, the priority was to ensure the comparability, compatibility and transparency of educational programs. To achieve this goal the European educational community needs to develop common approaches to teaching and learning, a common understanding of the content of qualifications and learning outcomes. A competence approach was to become the basis for developing a common methodology, which in turn grounds on an analysis of professional requirements prioritizing the competences required in a particular area of professional activity.

The TUNING project is directed to bringing educational structures closer in the countries of Bologna process.

A methodology for rethinking curricula and introducing it was developed within the TUNING project to make it comparable. Five topics were identified for the discussion of subject areas:

- general competences or universal skills;

- professional competences;

- role of ECTS as an accumulation system;

- approaches to learning, teaching and evaluation, and the role of quality improvement in the learning process (special attention to systems based on the internal institutional culture of quality assurance) [8].

One of the results of this project was the guidelines for the development of degree program profiles including program competences and program learning outcomes [8]. Let us consider the key positions of the guidelines.

The purpose of the developed methodological recommendations is to develop guidelines clearly for the formation of degree program profiles due to consideration of key program competences and qualitative formulation of learning outcomes.

The developed template for the preparation of the degree program profile takes the key position in the structure of the developed recommendations.

The profile of the program is a very concise document possessing the most relevant information about the competitive degree education program.

The profile determines the subject area or areas where the studies are conducted, defines the level of higher education, as well as specifies the features distinguishing this educational program from other similar programs [8]. 
The structure of the profile consists of seven components, namely:

- purpose of the educational program;

- characteristics of the educational program;

- learning and teaching style;

- program competences;

- list of program learning outcomes.

It is important to have links to common descriptors, national qualifications frameworks and reference points of subject areas developed by TUNING project while developing or updating an educational program.

Authors of methodological recommendations pay much attention to the design of educational programs and offer to use the developed algorithm under the creation of a new or updated degree educational program (Figure 2).

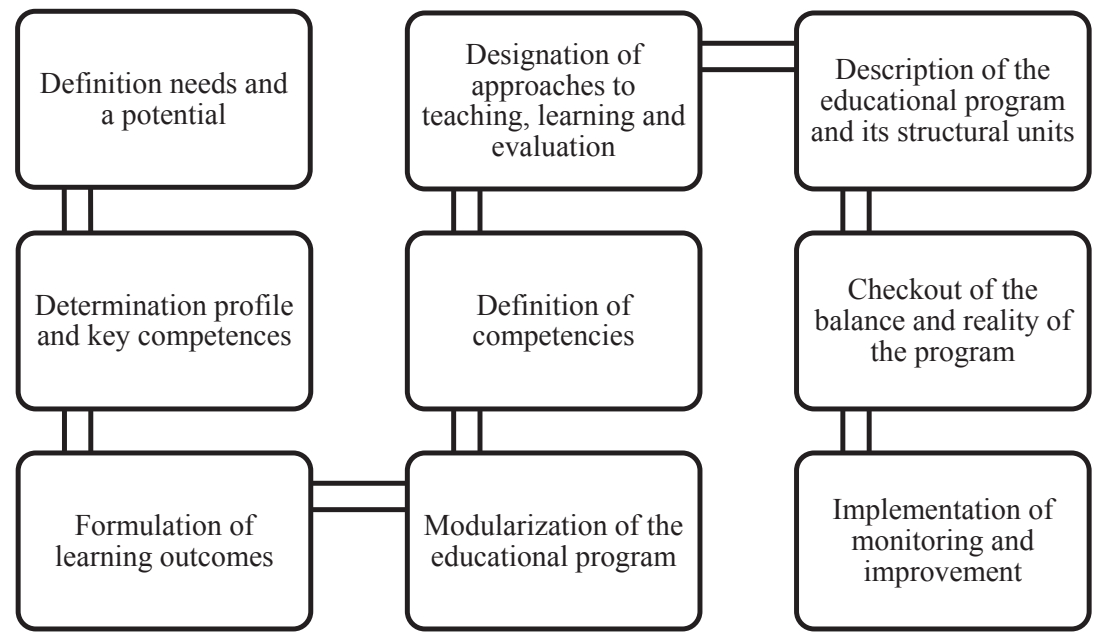

Fig. 2. Algorithm for the creation/improvement of educational programs

Source: according to the methodological guidelines [8]

The TUNING methodology presented in the guidelines can be used by universities to develop educational programs within the framework of the Bologna process for the creation of an academic culture aimed at meeting the needs of students. The TUNING project shows how to develop educational programs proceeding from results, taking into account how the graduate will be ready for real life after completing the learning process, as well as 


\section{Chapter 13. Pedagogical sciences}

taking into account the specific needs at the professional, personal and civil level. The TUNING project allows describing educational programs with the assistance of common terminology in all countries of Europe and beyond it, providing comparability, transparency and attractiveness of educational programs. The TUNING competence approach allows consulting with all stakeholders, including the students themselves, and clearly describing the specific objectives of each program. These goals all together are the profile of the university program.

The development and implementation of training programs should be continuously monitored and evaluated to determine whether the objectives are being met, and whether the goals remain urgent to the changes in the relevant subject areas. The tools and approaches of the TUNING project allow universities effectively to monitor, evaluate, and improve educational programs. Hence, the TUNING project offers a way to improve the quality at the level of educational programs.

The results of TEMPUS international project of the European Union "ALIGN: Achieving and Checking the Alignment between Academic Programmes and Qualification Frameworks" (2017) are set out in the "National Guidelines for the Harmonization of Academic Programmes and Qualifications Frameworks" [11].

ALIGN is a three-year international project supported by the State Reform EACEA No. 35/2012 of 6 Tempus competition for the selection of joint projects. The overall objective of this project is to improve the clarity, consistency and the ability to exchange qualification requirements through the introduction the mechanisms to bring academic programs into line with national qualifications frameworks in a HEI and mechanisms verifying these compliances in Quality Assurance Agencies (QAA). The project involves universities from the Eastern Partnership region Armenia, Russia, Ukraine. This will allow a deeper understanding of the needs of developing systems and the specifics of each individual institution.

The project objective is to enhance the comprehensiveness, coherence and transfer of qualifications through the establishment of mechanisms to achieve compliance with the qualifications framework (QF) and external quality assurance agencies (EQAA) to verify this compliance by higher educational institutions (HEI).

The specific objectives of the project are:

promotion better understanding by higher educational institutions and quality assurance agencies of the role of national qualifications frameworks, 


\section{Pochuieva Olha}

its structure, as well as differences between individual types and levels of student achievements;

formation of competences by higher educational institutions through writing (preparing) and evaluating learning outcomes according to particular types and levels of achievements, student success and facilitating studentoriented teaching and learning;

formation of competences by higher educational institutions through the regulation of the balance between educational programs and qualifications frameworks to facilitate the transfer of knowledge, general qualification requirements and the implementation of leading experience;

providing assurance agencies of the education quality with the ability to check the appropriateness of the required learning outcomes and the mechanisms for its evaluation at all levels through the introduction of a system ensuring a constant perception by each institution.

The main results of the project include:

development of facilities by higher educational institutions and the quality assurance agencies for balancing and coordinating educational programs and national qualifications frameworks;

development of mechanisms for arrangement with national qualifications frameworks (for higher educational institutions);

development of mechanisms for verification of conformity (for quality assurance agencies);

bringing 2 educational programs in each higher educational institution in accordance with European standards and requirements of the qualification frameworks and a pilot assessment of the developed mechanisms;

adaptation of the developed mechanisms in higher educational institutions, education quality assurance agencies and at the governmental level;

organization retraining courses for high school staff to evaluate academic performance and disseminate student-oriented learning and teaching.

The process of development and approval of educational programs consists of seven consecutive stages in the developed guidelines of the project.

\section{Conclusions}

Summarizing the analysis results of the European projects with the regard to the improvement of the higher education system (ESG), the development and update of educational programs (TUNING), the harmonization of educational programs and qualifications frameworks (ALIGN), it contributes 
to the integration of higher education of Ukraine into the European space implementing the conditions and policies of the Bologna Process. The results of generalization and development may be aimed at improving the indicators of internal quality assurance of higher education.

\section{References:}

1. Bologna Working Group on Qualifications Frameworks (2005). A Framework for Qualifications of the European Higher Education Area. URL: http:// www.ond.vlaanderen.be/hogeronderwijs/bologna/documents/050218_QF_EHEA.pdf

2. Standards and Guidelines for Quality Assurance in the European Higher Education Area (ESG) (2015). Kyiv: CS Ltd., 2015. 32 p.

3. Rashkevych M., \& Talanovoi V., Rashkevych M. (2015). Ievropeiska kredytna transferno-nakopychuvalna systema: dovidnyk korystuvacha, Lviv: Vydavnytstvo Lvivskoi politehniky, 2015. 106 p.

4. Zakon Ukrainy "Pro vyshchu osvitu" vid 01.07.2014 r. № 1556-VII. URL: http://zakon2.rada.gov.ua/laws/show/1556-18

5. Zakon Ukrainy "Pro osvitu" vid 05.09.2017 r. № 2145-VII. URL: http://zakon3.rada.gov.ua/laws/show/2145-1

6. Zakharchenko V. (2014). Natsionalna ramka kvalifikatsii ta osvitni programy. URL: http://erasmusplus.org.ua/2014-05-30-14-56-19/prezentatsii/ category/3-materialy-natsionalnoi-komandy-ekspertiv-shchodo-zaprovadzhenniainstrumentiv-bolonskoho-protsesu.htm

7. Lugovyi V.(2014). Natsionalna ramkakvalifikatsii ta Mizhnarodna standartna klasyfikatsiia osvity. URL: http://erasmusplus.org.ua/2014-05-30-14-56-19/ prezentatsii/category/3-materialy-natsionalnoi-komandy-ekspertiv-shchodozaprovadzhennia-instrumentiv-bolonskoho-protsesu.html?start20

8. Rashkevycha M. (2016). Metodychni rekomendatsii dlia rozroblennia profiliv stupenevykh program, vkliuchaiuchy programni kompetentnosti ta programni rezultaty navchannia / per. $\mathrm{z}$ anhl. Natsionalnoho eksperta $\mathrm{z}$ reformuvannia vyshchoi osvity Prohramy Erazmus+, d-ra tekhn.nauk, Kyiv. 80 p.

9. Nakaz Ministerstva osvity y nauky Ukrainy vid 01.06.2016 № 600 "Pro zatverdzhennia ta vvedennia v diiu Metodychnyh rekomendatsii shchodo rozroblennia standartiv vyshchoi osvity". URL: http://old.mon.gov.ua/ru/aboutministry/normative/5555

10. Natsionalna ramka kvalifikatsii : zatverdzhena Postanovoiu Kabinetu Ministriv Ukrainy vid 23 lystopada 2011 r. № 1341 URL: http://zakon5.rada.gov. ua/laws/show/1341-2011-\%D0\%BF

11. Ofitsiinyi sait Mizhnarodnogo proektu prohramy Yevropeiskogo Soiuzu TEMPUS "ALIGN: Dosiagnennia ta reguliuvannia balansu mizh osvitnimy programamy ta kvalifikatsiinymy ramkamy". URL: http://tempus.univ.kiev.ua/align/

12. Rashkevych Yu. M. (2014). Bolonskyi protses ta nova paradygma vyshchoi osvity: monografiia. Lviv: Vydavnytstvo Lvivskoi politehniky, 168 p.

13. Raskola L. A., \& Ruzhytska O. M. (2016). Teoretyko-metodychni zasady rozroblennia osvitnih prohram: Metodychnyi posibnyk / za red. O. V. Zaporozhchenko, V. M. Khmarskyi. - Odesa: Odeskyi natsionalnyi universytet imeni I. I. Mechnykova, 2016. 68 p. 